\title{
THE RUSSIAN RED CROSS IN THE CIVIL WAR*
}

Jean-François Fayet

University of Fribourg, Fribourg, Switzerland

Based on Russian and non-Russian materials, this article examines the history of the Russian Red Cross Society during the Civil War. The ascension of the Bolsheviks to power led to the breakup of the Russian Red Cross Society (RRCS) into a multitude of national and political associations, each claiming its material and symbolic heritage. When the Civil War began, these fragments of the RRCS no longer existed as effective sanitary organisations. But in autumn 1918, as epidemics threatened troops and civil populations alike, RC institutions had to be set up again urgently. In view of their experience and infrastructure, the Moscow, Omsk, and Kiev RC organisations quickly became decisive players in the Civil War with the Red Army and the White armies of Kolchak, Denikin, and Wrangel. In many fields, these RC organisations acted as a substitute for the state. They were responsible for nursing, nutrition, and evacuation. On the external front, the material assets of the former RRC had to be recovered, Russian soldiers arrested abroad assisted, and the exclusivity of the RC emblem defended. In conclusion, this article argues that the Russian Civil War was a dramatic theatre of modern humanitarian action for the entire international RC movement (the International Committee of the Red Cross and the League of Red Cross Societies) in terms of the practices and laws that had to be invented. Given its fragmentary nature, the mix of identity, social, and ideological conflicts, the civilian populations in the foreground, and the intermingling of national and international players, the Russian Civil War was a forerunner of the "new wars" of the late twentieth century.

Keywords: Civil War, Red Cross, humanitarian disaster, typhus, sanitary trains

На основе российских и зарубежных материалов рассматривается история Российского общества Красного Креста (РОКК) во время Гражданской войны. Приход большевиков к власти привел к распаду РОКК на множество национально-политических ассоциаций, претендовавших на его материальное и символическое наследие. С началом Гражданской войны эти фрагменты РОКК перестали существовать как эффективные здравоохранительные организации. Но осенью 1918 г., когда как войскам, так и мир-

* Citation: Fayet, J.-F. (2021). The Russian Red Cross in the Civil War. In Quaestio Rossica. Vol. 9, № 1. P. 188-202. DOI 10.15826/qr.2021.1.573.

Цитирование: Fayet J.-F. The Russian Red Cross in the Civil War // Quaestio Rossica. Vol. 9. 2021. № 1. P. 188-202. DOI 10.15826/qr.2021.1.573.

(c) Fayet J.-F., 2021

Quaestio Rossica • Vol. 9 • 2021 • № 1, p. 188-202 
ному населению угрожали эпидемии, пришлось срочно восстановить учреждения РОКК. Благодаря своему опыту и инфраструктуре московское, омское и киевское отделения Красного Креста стали решающими силами в Гражданской войне между Красной армией и белыми армиями Колчака, Деникина, а затем Врангеля. Во многих областях эти отделения Красного Креста заменяли государство. Они организовывали уход за больными и ранеными, питание и эвакуацию населения. На внешнем фронте их задачей стало возвращение активов бывшего РОКК - оставшихся за рубежом российских военнопленных, а также эксклюзивности эмблем и материального имущества. Автор приходит к выводу о том, что для всего международного движения Красного Креста (Международного комитета Красного Креста и Лиги обществ Красного Креста) Гражданская война в России стала театром современной гуманитарной деятельности, где реализовывались практика и законы, которые еще необходимо было разработать. Гражданская война в России, в которой на первый план выдвигалось гражданское население и где смешивались национальные и международные факторы, стала предвестницей «новых войн» конца ХХ в.

Ключевые слова: Гражданская война, Красный Крест, гуманитарная катастрофа, тиф, санитарные поезда

The Russian Civil War (RCW) was a dramatic theatre of modern humanitarian action for the entire Red Cross movement - the national sections, the Russian Red Cross Society (RRCS), the International Committee of the Red Cross (ICRC), and the League of Red Cross Societies founded in March 1919. This manifested itself in the practices that had to be urgently invented as the RCSs constantly moved to keep up with the changing position of the fronts. In terms of law, the aim of the ICRC was to standardise within international humanitarian law the extension of its field to intervention in civil wars. This had appeared on the agenda of the International Conference of the Red Cross held in Washington in May 1912, but was removed after the fierce hostility of the Russian representative [Bugnion, p. 286; Moreillon, p. 36-37]. This would haunt the RC movement for the entire Civil War and long afterwards.

Before entering the Civil War, the RRCS found itself caught up in the revolution. The RRCS was certainly not a driving force in these events. However, thanks to its network of medical and healthcare organisations across the country and on the north, west, and south fronts, it constituted a privileged observatory for the upheavals in 1917. It is particularly interesting to follow the passion for democracy in an institution that embodied a system of honorary positions and other privileges of the autocratic regime [Чистяков, с. 132]. Under the influence of revolutionary events, RC workers organised themselves into congresses or soviets, especially on the western front, where they elected a new committee and soviet in May [ГАРФ. Ф. 9572. Оп. 1. Д. 20. Л. 1 и посл.]. These new bodies adopted resolutions regarding the democratisation of the RRCS, the removal of certain 
executives, and the integration of ordinary workers into the administration. In July 1917, the National Conference of Red Cross Workers refused to hold a discussion with the directorate general (DG) of the RRCS, which was supported by the Russian Provisional Government. Doctors organised counter-conferences, like that in Minsk in October 1917 [ГАРФ. Ф. 4094. Оп. 1. Д. 28. Л. 1].

We can thus follow in the archives a genuine class struggle, one which led to a division within the RC. This passion for democracy was accompanied by salary claims from basic workers: they demanded up to 350 roubles per month for healthcare workers and over 400 roubles for sisters of mercy [ГАРФ. Ф. 4094. Оп. 1. Д. 24. Л. 18]. The new RC bodies had to ask for additional loans from the government to meet these requirements [E. A. Frick "Report" (October 1917). ACICR. CR00 /50a-165]. At the same time, RC institutions had to introduce an eight-hour working day. In summer 1917, doctors stated that it was impossible to work because of difficulties with their staff. Desertion occurred in RC stations and infirmaries along the front [ГАРФ. Ф. 4094. Оп. 1. Д. 16. Л. 116]. The RC could certify that a soldier had been demobilised. There was also a stampede of leaders running off with the reserves to join pockets of resistance [ГАРФ. Ф. 4094. Оп. 1. Д. 23. Л. 18]. Finally, medical and nursing infrastructure collapsed following the Sovnarkom decree of December 1917 that ordered the immediate demobilisation of RRCS personnel (2,500 doctors and 30,000 nurses) [Беляева, с. 127]. The advance nursing detachments, transports, and mobile infirmaries had to be dissolved. When the Civil War began, the RRCS no longer existed.

\section{Multiple rebirths: the Red Cross as an allegory of the territorial and political breakup of Russia}

Nothing was more alien to Bolshevik culture than the bourgeois philanthropy embodied by the RC. Inspired by Christian values and dominated by the aristocracy, the RRCS represented, in the eyes of revolutionaries of all tendencies, a perfect example of an anachronism [Toman, p. 9]. During the preparation for the October uprising, the Military Revolutionary Committee of the Petrograd Soviet had thus set up an independent healthcare organisation, made up exclusively of factory workers who were to work together with the Red Guard: the Proletarian RC. After the revolution, the Bolsheviks tried to merge the Proletarian RC with the former RС [ГАРФ. Ф. 3341 Оп. 1. Д. 54. Л. 2-9]. However, the directors of the former RC (the DG of the RRCS presided over by Count P. N. Ignatieff and the Central Executive Committee of Red Cross Workers) were opposed to any interference from the authorities. Furthermore, the Sovnarkom declared the nationalisation of the RRCS's assets, the dissolution of its central administration, and the establishment of a reorganisation committee in a decree dated 6 January 1918 [ГАРФ. Ф. 9501. Оп. 1. Д. 1. Л. 7]. Those in power also ordered the arrest of several members of the central management (including N. N. Pokrovsky, former minister of foreign affairs and 
chairman of the RC at the time) who had expressed their opposition to the new regime. The decree on the nationalisation of assets was to have serious consequences for the RRC.

The decision was initially mainly theoretical due to the country's political fragmentation: most of the 118 hospitals and the 2,255 medical and nursing centres on the front were beyond Bolshevik control. The governments of the new states carved out of the former Russian Empire (Finland, Poland, the Baltic states, Ukraine, Georgia, and Armenia) handed over RRC assets to their new national RCS: buildings, equipment, and hospital ships [ГАРФ. Ф. 9501. Оп. 6. Д. 8. Л. 94]. When military hostilities resumed in February 1918, the German, Austrian, and Turkish armies confiscated such supplies as booty on the pretext that they were no longer protected by the conventions. In Caucasia, all RC assets were looted by Turkish soldiers, along with the Armenians and Georgians [Беляева, c. 143]. Due to foreign intervention, the Soviets lost yet more hospitals and infirmaries. Added to these initial consequences was a loss of respect for the RC emblem and the legal protection of personnel by the conventions. The decree ultimately aroused the ICRC's indignation, which expressed in the April 1918 issue of its journal "its disapproval of the unspeakable conduct of the Russian revolutionaries with respect to the Russian Red Cross Society". Edouard Odier, the Swiss ambassador in Petrograd and the vice-chairman of the ICRC, took it upon himself to entrust Edouard Frick, a Swiss citizen in Russia who had joined the RRCS during the war, with a mandate to assist the RRCS.

During spring 1918, Frick and the Central College of the Administration of RC Affairs managed to persuade the Sovnarkom to publish two additional clauses in the decree of 6 January [ACICR. CR 00/50a-165]. The first was signed by Lenin on 3 May (20 April) 1918, according to which "the Russian Red Cross, in its capacity as the national section of the International Association of the Red Cross, whose activity is based on the Geneva Conventions of 1868 and 1907, has not been banned" [CICR. p. 187-188]. A second was signed on 31 May confirming that "all the international conventions and agreements related to the Red Cross, to which Russia has adhered... have been recognised by the Russian Soviet Government" [ГАРФ. Ф. 9501. ОП. 1. Д. 1. Л. 8]. Finally, on 20 November, the RRC assembly ratified articles of association, emphasising the continuity of the RRCS in relation to the former society [ГАРФ. Ф. 9501. Оп. 6. Д. 6. Л. 20]. Generally speaking, the Bolsheviks continued to think that "the triumph of the world revolution and the transformation of the international community into a free federation of Soviet republics, by making the functions of the Red Cross superfluous and irrelevant, were condemning it to a gradual death" [ГАРФ. Ф. 9501. Оп. 6. Д. 8. Л.14]. However, this exception to the Soviet government's policy of disowning its predecessor's treaties should have enabled RRC stakeholders to gradually remove the harmful effects of the initial measures, particularly those related to the confiscation of assets [ГАРФ. Ф. 3342. ОП. 1. Д. 112. Л. 87]. Frick also persuaded the Soviets to send a representative of the Soviet RC to Geneva to defend their interests. 
The mission was entrusted to Dr S. Y. Bagotsky, a relative of Lenin [Fayet, 2014, p. 57]. Dashing Soviet hopes, however, the ICRC decided to consider the "Moscow Red Cross" [ГАРФ. Ф. 9501. Оп. 6. Д. 6. Л. 8] a new society, for which admission to the movement required a new examination. For the international committee, recognition of this society was also hindered by the fact that the former RRCS had not ceased its activities.

The Civil War led to the formation of several bodies that were opposed to the Soviet government and that claimed the RRCS's heritage [ГАРФ. Ф. 9501. Оп. 6. Д. 17. Л. 61-65; Ипполитов, с. 34-53]. The first was the Provisional DG of the RRC (Временное Главное Управление РОКК: VGU ROKK), formed in Samara in late September 1918 under the chairmanship of A. N. Chalachnikov (and subsequently M. L. Kindiakov). In October, the VGU ROKK moved to Omsk. This directorate also had an office in Copenhagen (later Stockholm) run by N. A. Czamanski, one of those responsible for the former central administration. The VGU ROKK, which put itself at the service of the Provisional Government, was to play a very important role in the enrolment of former Russian prisoners of war returning from Germany and Austria-Hungary into Admiral Kolchak's army. As for the second organisation, the Provisional Directorate for the Affairs of the RC, this was set up in Kiev on 16 November 1918. Containing five members of the former DG under the chairmanship of the former senator B. E. Ivanitski, it had hospitals and medicine storage facilities on the southwestern front, where the army of volunteers commanded by Denikin was fighting. There were also RRC representatives in the Supreme Administration of the Northern Region [Беляева, с. 127] and in Estonia for N. N. Yudenich's troops. In June 1919, aware of the need to have common representation to endorse their authority abroad, the representatives of the Kiev and Omsk committees met in Paris at a general council for the affairs of the RRC abroad under the chairmanship of Count Paul Ignatiev [ACICR. CR00/50a-165]. Following the advice of the ICRC [ACICR. CR 00/50b-173], they reactivated the Central Council of the RC, maintaining its composition from before the October Revolution. This society, hostile to all contact with the communists, was financed by ambassadors at the Conference of Paris, who were chaired by V. A. Maklakov and actively supported by the Entente governments. Each of these versions, political or national, of the former RRCS claimed the RC's heritage and its recognition by the International Committee. While the ICRC refused all recognition due to the "shifting" nature of the situation [ГАРФ. Ф. 9501. Оп. 6. Д. 6. Л. 10], it nonetheless intended to collaborate with all of them in order to deal with the humanitarian emergency.

\section{On all fronts of the humanitarian disaster: the Civil War as a theatre of modern humanitarianism}

The breakdown of RRCS infrastructure, personnel, and resources coincided with a humanitarian crisis. All reports confirm the immensity of the "suffering" populations to be cared for, aided, or protected. Around 2.2 mil- 
lion former prisoners of war were present in Russian territory: Austrians, Hungarians, Germans, Turks, and Bulgarians [Davis]. In many places, the camps had been without rations for several months, obliging the prisoners to organise themselves and to take part in the civil war. But there were also injured and sick Russian soldiers, civilian populations, Jews subjected to pogroms [Будницкий], political prisoners, refugees, and the destitute. In addition to the physical and psychological violence related to the Civil War, the population was suffering from epidemics: louse-borne typhus spread with unprecedented rapidity in the desperate conditions during 1918-1922 (between 4.4 million and 5.2 million people died), while Spanish influenza («испанки») and cholera also raged unabated [Ferrière, p. 277; Patterson, p. 173]. The population also faced hunger [Adamets]: Russia experienced several years of malnutrition and scarcity, accompanied by deficiency-related diseases such as scurvy. It was mainly hunger that brought the Civil War to an end. We should also mention the evacuations due to the movement of the front: an entire people was on the move, bringing with them lice [Argenbright, p. 260].

$\mathrm{RC}$ personnel were themselves victims of the violence. The list of violations of the Geneva and the Hague conventions concerning nursing organisations and RC personnel was a long one: attacks against nursing staff; the torpedoing of hospital ships; the bombing and pillaging of nursing trains, quarantine stations, and ambulances; and the murder of nurses, sisters of mercy, and doctors while they were carrying out their work. In Irkutsk, Semienov had hanged members of the Swedish RC accused of spying. When Minsk was taken by Polish legionnaires (summer 1919), several members of the Soviet RC were executed and others arrested. When the Red Army took the Crimea, most RC workers, several doctors and nurses, were arrested or shot. Each of the RRCSs made a list of the atrocities committed by the enemy [Données sur la terreur en Russie; Quelques documents concernant l'activité de l'ancienne organisation de la Croix-Rouge russe]. Above all, we should remember that the mortality rate among nursing staff in the epidemic centres was $100 \%$.

The winter of 1918-1919 was characterised by intense activity from the RC, which had to demonstrate its creativity. Everywhere, its staff had to take stock (by sending inventory teams) [ГАРФ. Ф. 4094. Оп. 1. Д. 269. Л. 2], rebuild or find new buildings and means of transport, remobilise and train personnel, find funds, organise storage facilities, and set up reserves. They were able to make the most of experience acquired during the Great War, particularly in the field of vaccination due to the epidemics that had threatened the armies [Беляева, c. 125]. They once again set up anti-epidemic detachments, control and disinfection stations, nutrition centres, and bacteriological laboratories [ГАРФ. Ф. 4094. Оп. 1. Д. 158. Л. 1]. As for the soldiers, most of the activities of humanitarian workers were concentrated around the railways. All RCs used sanitary trains: nursing trains, disinfection, nutrition, and surgery carriages, storage trains, and bath trains [Foust]. 
In addition to the tasks common to all RCs - medical and nursing assistance for civilian and military victims of the war, the fight against epidemics and hunger, the training of personnel, and the return of prisoners of war - we can highlight the specific features of each front in terms of the humanitarian organisations. In spring 1918, the sanitary situation inside the Russian Soviet Republic had deteriorated to the point of threatening the health of troops, hospital patients, and the surrounding civilian population [ГАРФ. Ф. 4094. ОП. 1. Д. 23. Л. 54]. However, the Soviet military and sanitary authorities were only in their early stages of development [Hutchinson, 1990; Weissman, p. 97-101]. The new personnel trained by the Proletarian $\mathrm{RC}$ remained insufficient. Thus, despite their reluctance, the communists had to rely on the experience of the RC personnel to set up the Red Army's medical service on the front [Беляева, c. 127]. The RC (Центрокрест), which had in June 1918 created an emergency mobilisation commission, became the main representative of the People's Commissariat for Health (Наркомздрав, NKZ) and the health directorates (Главным санитарным управлением Главсанупра), with which it shared medical and nursing centres, medicines, and other healthcare services [ГАРФ. Ф. 9572. Оп. 1. Д. 27. Л. 1 и посл.].

From March 1919, the RC's structure was fully adapted to the requirements of the Red Army. Service in RC institutions was equivalent to that of soldiers, with additional administrative control. The plenipotentiary representative of the RRCS with the Soviet armies had extensive powers regarding the movement of doctors, nurses, and maintenance personnel and the supply of medical equipment and money to subordinate institutions [Беляева, с. 131-133]. However, this RC was no longer an independent NGO. The election in July 1919 of Dr Zenovi Soloviev, the chief of the military and nursing department of the NKZ, as head of the RC brought an end to the recent tensions between the $\mathrm{RC}$ and the government authorities. The tendency to subordinate the RC's nursing institutions to the army's nursing service and the Narkomzdrav continued throughout the Civil War and beyond [ГАРФ. Ф. 4094. Оп. 1. Д. 269. Л. 60]. During the reconquest of territories (Ukraine), the assets of the former RC were transferred to the military and nursing departments of the NKZ.

In Siberia, humanitarian stakeholders were faced with some specific problems: the vastness of the region concerned (in spring 1919, Kolchak controlled $300,000 \mathrm{~km}^{2}$ ), difficulties with food supplies (they had to send missions to Kharbin and Japan), the shifting nature of the front, and a ceaseless influx of new refugees. However, the Provisional DG of the RC in Omsk was politically and financially sustained by Kolchak (he provided $95 \%$ of its budget) [Ипполитов, с. 58]. Its chairman, former senator A. N. Shelashnikov, and its directors were deeply involved in government work. They frequently met with the ministers of health, transport, foreign affairs, the interior, and trade. Thanks to the government's support, all the charitable organisations of the Unions of Towns and the zemstvos had been placed under the RC's authority. This merger became necessary during the mo- 
bilisation against the typhus epidemic that broke out in December 1918 in Chelyabinsk and threatened the whole of Siberia. In August 1919, the entire territory was divided into three parts in connection with the need for nursing services and evacuation [Ипполитов, с. 64]. The army zone welcomed the wounded and the sick, the rear front zone was where former prisoners of war were held, and the state zone was where the influx of refugees was concentrated. The state zone itself was divided into two, one stretching as far as Lake Baikal (interior: И. А. Куракин) and the other in the Far East. On the front, the RC commissioner-in-chief (Главноуполномоченный) was promoted to the rank of deputy commander to the chief of staff. He was responsible for nursing missions and the evacuations to Omsk, Irkutsk, Vladivostok (for the Siberian armies) and China (for General Belov's Southern Army). In many fields, the RC acted as a substitute for the state. This status explains the government's gradual attempt to subordinate the RC. Medical and nursing assistance in wartime could not be carried out on an exclusively "voluntary" and "independent" basis.

In terms of the relative efficiency of the system of medical, nursing, and nutritional institutions set up by the $\mathrm{RC}$, it needs to be considered in view of the context: the constant influx of wounded, sick, and refugees and the reduction in the number of personnel made continual restructuring a necessity. Of course, the material and human losses were enormous during the evacuations because of typhus and water shortages. The lack of fuel for trains and attacks by looters slowed down the convoys. Trains were often confiscated by Czech and Polish troops. In January 1920, the Provisional Council of the Administration of the Siberian People attempted to confiscate RC assets. However, the personnel resisted, which led to the Siberian RC organisation being broken up into several centres abroad [Ипполитов, с. 106].

The activities of the RRC in $\mathrm{Kiev}^{1}$, took place over a smaller area with plentiful and excellent hospital infrastructure: 496 establishments with 36,870 beds (double the numbers in Siberia). Although this RC had fewer problems with food supplies, it was faced with almost constant retreat. In January 1919, the provisional directorate for RC affairs in Kiev had to transfer its activities to Odessa, then to the Kuban (Ekaterinodar - Krasnodar), and finally to the Crimea. With each evacuation, the RC lost some of its assets. The final days in the Crimea were tragic, beset by the looting of storage facilities and hospitals and the arrest of personnel [Ипполитов, с. 113].

To briefly illustrate the specific features of the work of the RRC in Ukraine, we have to change our perspective to place ourselves within a specific institution: an RC hospital in Kiev run since 1915 by Dr G. Lodygensky, a tsarist officer assigned to the RC's $22^{\text {nd }}$ nursing detachment [Лoдыженский]. Located in the city centre, the Grand Duke Mikhail Hospital had 300 beds reserved for officers. In spring 1917, it was hastily renamed "the Kiev Hospital of the Russian Red Cross Society" and opened its doors

${ }^{1}$ This Russian Red Cross in Kiev should not be confused with the Ukrainian Red Cross Society founded on 15 April 1918 under the chairmanship of professor Petrowsky. 
to all soldiers. After the Bolsheviks seized power in January 1918, the capital of Ukraine changed hands thirteen times. The building was in turn requisitioned by Ukrainian nationalists, the Red Army, German troops, the army of Hetman Skoropadsky, again by Petliura's nationalists, and, finally, by the Soviets. The hospital continued to operate under the different regimes despite numerous arrests.

The ICRC, the neutral RCSs, and the several national RCSs were very keen to participate in the humanitarian experience that was the Russian Civil War. This was a period during which humanitarianism was being remade by the appearance of new players or competitors in the "humanitarian market": the League of RCSs, the League of Nations, the International Save the Children Union, and the American Relief Administration [Hutchinson, 1996, p. 279]. For the International Committee, it was a question of extending its activity to encompass civil war [Fayet, 2015, p. 62]. In addition to Frick's work in Petrograd and Moscow [ACICR. CR 00/50a-165], the ICRC sent missions to Ukraine (1918) and Siberia (1919-1920) [Montandon; Piana] to repatriate prisoners of war from the Central Powers. The RCSs from neutral countries, such as Sweden and Denmark, were also deeply involved [Енсен]. This was the case in the Soviet arena, where a Moscow committee responsible for assisting prisoners of war and political prisoners was to operate until summer 1919, and in White territories such as Kiev, where the Danish and Swiss RCSs supported an ICRC to relieve victims of the Civil War [ГАРФ. Ф. 3341. Оп. 1. Д. 200. Л. 3]. The Scandinavian RCSs sent the first nursing expeditions to Omsk in 1918 and were responsible for establishing a cordon sanitaire against epidemics in Caucasia. The RCSs of the Entente countries were present alongside their troops in the north, Ukraine, and Siberia [Polk, 2004; Polk, 2012]. The American, Canadian, and British RCSs made a major contribution to combating typhus [Irwin, p. 91]. The arrival of American RC supplies allowed for the first storage facilities to be set up in Omsk and Perm. In the Crimea, Wrangel's RC received aid from its French counterpart. Support from the foreign RCSs continued during the White retreat, defeat, and exile to Turkey, Yugoslavia, Bulgaria, Czechoslovakia, France, and Belgium. It was also the foreign RCSs, assisted by the ICRC and especially by High Commissioner Nansen, that organised the return of prisoners of war in spring 1920. Most of these RCSs would return to Russia in 1921 as part of the campaign against famine.

\section{The reconquest of Red Cross assets and Russian POWs abroad}

Russian soldiers in prison abroad constituted a priority issue for the RCSs of both camps from the start of the Civil War. From Brest-Litovsk at the end of 1918, the Soviets had the advantage because their diplomatic representatives and RC delegates were legally welcomed by the Central Powers and neutral countries. The support provided by the ICRC in organising the first returns of POWs sparked criticism from the Entente governments and White émigrés, who did not wish to see the Red Army receive any reinforcement during the Civil War [Fayet, 2014, p. 80]. After the 
Armistice in November 1918, the Allies imposed the Inter-Allied Commission upon Germany, which was responsible for controlling the repatriation of Russian POWs. With the exception of S. Y. Bagotsky, whose presence in Switzerland had been imposed by the ICRC, all delegates of the Moscow RCS were expelled and sometimes even executed, as in Poland [ГАРФ. Ф. 3341. Оп. 6. Д. 323. Л. 78]. During winter 1918-1919, almost one million Russian prisoners of war left Germany on their own account. Many died en route or returned to the camps. The Inter-Allied Commission therefore prohibited any repatriation between Germany and Soviet Russia until March 1920. However, it did authorise around 80,000 prisoners of war to return to zones controlled by the White Army. In Berlin, prisoners of war were complaining that "while the representative of the Russian military mission openly enrols soldiers for the White Armies, the representative of the RRC, Baron Wrangel, offers no aid to those who have signed up to go to the front” [ГАРФ. Ф. 9501. Оп. 6. Д. 39. Л. 46, 65]. There was a similar situation in Vienna and Switzerland, where agents of the tsarist RC were working to enrol internees for Denikin's army [ГАРФ. Ф. 9501. ОП. 6. Д. 11. Л. 7]. The question of the forced enrolment of prisoners of war also concerned the protagonists of the Civil War. Between 50,000 and 90,000 POWs from the Central Powers joined the Red Army.

Despite reminders from the ICRC about the need to establish an "absolute distinction between the missions acting in a military capacity and the missions of the Red Cross" [ГАРФ. Ф. 9501. Оп. 6. Д. 7. Л. 31], the confusion was set to continue. The methods for repatriating the last prisoners of war from the Eastern Front were defined at the Conference of Berlin (18-19 May 1920), bringing together, at the invitation of the ICRC, Dr Fridtjof Nansen, the high commissioner of the League of Nations, and the representatives of the German, Austrian, Hungarian, and Soviet governments. However, the Polish-Soviet War and the movement of the front to Ukraine prevented any land transport until the autumn. We highlight the fact that, unlike in the Second World War, there were no forced returns.

The second reconquest concerned symbolic assets: the exclusivity of the RC emblem. Since its reconstitution in 1918, the RRCS, like the other variations of the $\mathrm{RRC}$, had continually requested recognition by the International Committee. Although the committee had been the first to favour sending and maintaining a Soviet RC representative in Switzerland [ГАРФ. Ф. 9501. Оп. 6. Д. 6. Л. 15], it nonetheless remained opposed to official recognition. The decision was difficult for the ICRC, whose links with the former RRCS had always been excellent [Fayet, 2015, p. 57]. The ICRC was mainly concerned about being the first international organisation to recognise the Soviet regime through its national RCS. However, recognition of the Moscow RC was a condition for allowing the ICRC to continue its presence on Soviet territory. The decision was formalised on 15 August 1921, the same day as the opening of a conference in Geneva on aid for victims of the Russian famine. But contrary to the principle of unity according to which "there can be only one RCS in any one Country", this recognition 
was not in any way expressed by the breakdown of the real relations that the ICRC maintained with the White RRC organisation, in view of "the humanitarian aid that it continued to provide outside the territory of the Soviet Republic to Russian refugees abroad" [Toman, p. 30]. However, it would allow the Soviets to rely on the eleventh resolution of the $10^{\text {th }}$ International Conference of the Red Cross, inviting RCSs to agree to foreign RCSs that wished to send a representative abroad to work alongside their compatriots [ГАРФ. Ф. 9501. Оп. 6. Д. 36. Л. 65]. In a few months, the Soviets thus appointed RC delegates in more than fifteen countries, including the United Kingdom, Austria, Bulgaria, China, Denmark, the United States, Italy, Latvia, Lithuania, Poland, and Czechoslovakia, later joined by representatives in Germany, France, Greece, and Japan [Fayet, 2014, p. 218].

In the absence of Soviet consulates abroad, these Soviet RC delegates had to recover the material assets of the RRCS and, if possible, protect the interests of Soviet citizens. The real estate assets comprised numerous buildings, orphanages, hospitals, and sanatoriums acquired by the RRCS in several Mediterranean countries (France, Greece, Bulgaria, and Montenegro). But there were also some ships and trains. For example, the Soviet RC identified in 1926180 merchant vessels, 54 ice-breakers, and 18 miscellaneous buildings brought over for French intervention during the Civil War [ГАРФ. Ф. 9501. Оп. 1. Д. 140. Л. 1-9]. As for financial assets, they consisted of money invested abroad, such as the Empress Fund. This mission continued for several years with only patchy success: most governments continued to support the representatives of the former RRCS organisation based in Paris. Two court judgements from Paris in January 1925 and January 1927 regarding a sum of 212,546 French francs deposited by the former RRC organisation in a French bank dismissed the Soviet claims. The judge argued that the former RRC organisation was a private association, so the French courts could not rule for expropriation in favour of the Soviet government [ГАРФ. Ф. 9501. Оп. 1. Д. 154. Л. 183-214]. The RC delegates had more success with the private assets of Soviet citizens: the pensions of war veterans, legacies, and insurance policies taken out by Russians in the United States, Latin America, and Canada. This enabled the RRCS to bring in almost two million dollars in 1928 and another eight million in 1929 [ГАРФ. Ф. 9501. Оп. 5. Д. 52. Л. 49].

The issue of humanitarian assistance in the context of civil wars was at the core of the discussion at the $10^{\text {th }}$ International Red Cross Conference in Geneva from 30 March to 7 April 1921. Taking advantage of the absence of the Soviets [ГАРФ. Ф. 9501. Оп. 6. Д. 6. Л. 52], the White RRC delegation attempted to pass a resolution authorising RCSs to intervene directly in Russia by extending their obligatory activities to aiding the victims of civil wars. There was nothing theoretical about the matter. The Bolsheviks looked certain to win the Civil War, but difficulties with food supplies were 
causing disturbances in Moscow and Petrograd. On 7 March 1921 (three days after the start of the Kronshtadt Rebellion), the directorate of the White RRC in Paris declared its intention to send supplies to the insurgents [ГАРФ. Ф. 3341. Оп. 2. Д. 52a Л. 299-300].

The adoption of a resolution authorising the RCSs to intervene during civil wars would have given international legal legitimacy to these plans for interference. The first version of a resolution likening political prisoners to prisoners of war protected by the Hague Convention was adopted on 6 April at the commission. However, on the next day, delegates from Germany, Finland, Sweden, Switzerland, and Lithuania became concerned about the consequences of a resolution aimed directly against Soviet Russia, which could later be turned on countries fighting the revolution [Там же. Л. 290]. Resolution XIV was therefore stripped of its restrictive nature by making the intervention of RCSs subject to "the consent of the Government of the country where civil war was being waged" [Bugnion, p. 294; Moreillon, p. 62]. The USSR never implemented this. However, political prisoners, classified as "state criminals" by the Soviets, were not completely deprived of assistance. Throughout the Civil War, the Political RC (Российского общества Красного Креста для помощи политзаключенным or PKК) of Peshkova, Vera Figner, and Muraviev operated legally [Мухутдинов]. By providing material and legal aid to political prisoners and their families, the PKK became a point of contact between the justice commissariat of the Russian Soviet Federative Socialist Republic (RSFSR) and the Cheka. This experience was relived in Spain during the Civil War: it was not until 1977 that it was standardised in international agreements. With its fragmentary nature, mix of identity, social, and ideological conflicts, civilian populations in the foreground, and intermingling of national and international players, the Russian Civil War was in many ways a forerunner of the new wars [Kaldor] of the late twentieth century.

\section{Список литературы}

Беляева М. В. Российское общество Красного Креста в истории России 18671921 гг. : дис. ... канд. ист. наук. Ставрополь : [Б. и.], 2002. 211 с.

Будниикий О. Российские евреи между красными и белыми (1917-1920). М. : РОССПЭН, 2007. 547 c.

ГАРФ. Ф. 3341. Оп. 1. Д. 54, 200; Оп. 2. Д. 52a; Оп. 6. Д. 323; Ф. 3342. Оп. 1. Д. 112; Ф. 4094. Оп. 1. Д. 16, 23, 24, 28, 158, 269; Ф. 9501. Оп. 1. Д. 1, 140, 154; Оп. 5. Д. 52; Оп. 6. Д. 6, 7, 8, 11, 17, 36, 39; Ф. 9572. Оп. 1. Д. 20, 27.

Енсен Б. Гуманитарная помощь и политика: миссия датского Красного Креста в Советской России. 1918-1919 // Первая мировая война : Пролог ХХ века / отв. ред. В. Л. Мальков. М. : Наука, 1998. С. 515-536.

Ипполитов С. С. Российская благотворительная деятельность на территории действий белых армий и в эмиграции (1918-1924 гг.) : дис. ... канд. ист. наук. М. : [Б. и.], 2000. $195 \mathrm{c}$.

Лодыженский Ю. И. От Красного Креста к борьбе с коммунистическим Интернационалом. М. : Айрис Пресс, 2007. 576 с.

Мухутдинов А. А. Политический Красный Крест : История создания и деятельности; опыт изучения массовых источников : дис. ... канд. ист. наук. М. : [Б. и.], 1998. 157 с. 
Чистяков О. В. Организационное устройство и деятельность Российского общества Красного Креста в годы Первой мировой войны (1914-1918 гг.) : дис. ... канд. ист. наук. М. : [Б. и.], 2009. 154 с.

ACICR. CR 00/50a-b-c. B Mis 0. B MIS 54.

Adamets $S$. Guerre civile et famine en Russie. Le pouvoir bolchevique et la population face à la catastrophe démographique 1917-1923. Paris : Inst. d'Etudes slaves, 2003. 476 p. Argenbright R. Lethal Mobilities. Bodies and Lice on Soviet Railroads, 1918-1922 // J. of Transport History. Vol. 29. 2008. № 2. P. 259-276. DOI 10.7227/TJTH.29.2.7.

Bugnion F. Le Comité international de la Croix-Rouge et la protection des victimes de la guerre. Genève : CICR, 2000. 1444 p.

CICR. Rapport général du CICR sur son activité de 1912 à 1920. Genève : CICR, 1921. $259 \mathrm{p}$.

Davis G. H. National Red Cross Societies and Prisoners of War in Russia, 1914-18 // J. of Contemporary History. Vol. 28. 1993. No. 1. P. 31-52.

Données sur la terreur en Russie présentées par le Comité central de l'ancienne organisation de la Croix Rouge Russe au Comité international de la Croix Rouge à Genève. Paris : Ed. de la Société russe de la Croix-Rouge, 1922. 29 p.

Fayet J.F. VOKS : le laboratoire helvétique : Histoire de la diplomatie culturelle soviétique durant l'entre-deux-guerres. Genève : Georg, 2014. 598 p.

Fayet J.-F. Le CICR et la Russie : un peu plus que de l'humanitaire // Connexes, les espaces postcommunistes en question(s). Bruxelles : Univ. de Geneve. 2015. P. 55-74.

Ferrière F. Situation épidémique de la Russie // Rev. intern. de la Croix Rouge. 1922. № 53. P. 273-283.

Foust C. M. Sanitary Trains and Epidemic Control: The American Red Cross in Siberia during the Russian Civil War // Actas del XXXIII Congreso Internacional de Historia de la Medicina / eds. J. Carrillo, G. de Ros. Seville : Sociedad Española de Historia de la Medicina, 1994. P. 1005-1010.

Hutchinson J. F. Politics and Public Health in Revolutionary Russia. Baltimore : Johns Hopkins Univ. Press, 1990. 253 p.

Hutchinson J. F. Champions of Charity : War and the Rise of the Red Cross. Colorado : Westview Press, 1996. 448 p.

Irwin J. F. The Great White Train: Typhus, Sanitation, and U. S. International Development during the Russian Civil War // Endeavour. 2012. No. 36. Vol. 3. P. 89-96. DOI 10.1016/j.endeavour.2012.03.001.

Kaldor M. New and Old Wars : Organized Violence in a Global Era. Cambridge : Polity Press, 2012. 268 p.

Montandon $G$. Deux ans chez Koltchak et chez les Bolchéviques pour la Croix-Rouge de Genève, 1919-1921. Paris : Alcan, 1923. 318 p.

Moreillon J. Le CICR et la protection des détenus politiques. Lausanne : L'Age d'Homme, $1973.303 \mathrm{p}$.

Patterson K. D. Typhus and Its Control in Russia, 1870-1940 // Medical History. 1993. No. 37. P. 361-381.

Piana F. The Dangers of 'Going Native': George Montandon in Siberia and the International Committee of the Red Cross, 1919-1920 // Contemporary Europ. History. Vol. 25. 2016. № 2. P. 253-274. DOI 10.1017/S0960777316000060.

Polk J. A. The Canadian Red Cross and Relief in Siberia, 1918-1921 : MA Thesis. Ottawa : [S. n.], 2004. 243 p.

Polk J. A. Constructive Efforts: The American Red Cross and YMCA in Revolutionary and Civil War Russia, 1917-24: PhD Thesis. Toronto : [S. n.], 2012. 507 p.

Quelques documents concernant l'activité de l'ancienne organisation de la CroixRouge russe. Genève : Ed. de la Société russe de la Croix-Rouge, 1923. 40 p.

Toman J. La Russie et la Croix-Rouge (1917-1945) : La Croix-Rouge dans un Etat révolutionnaire et l'action du CICR en Russie après la Révolution d'octobre 1917. Genève : Inst. Henry-Dunant, 1997. 89 p. 
Weissman N. B. Origins of Soviet Health Administration: Narkomzdrav, 1918-1928 // Health and Society in Revolutionary Russia / ed. by S. Solomon, J. F. Hutchinson. Bloomington : Indiana Univ. Press, 1990. P. 97-101.

\section{References}

ACICR. CR 00/50a-b-c. B Mis 0. B MIS 54.

Adamets, S. (2003). Guerre civile et famine en Russie. Le pouvoir bolchevique et la population face à la catastrophe démographique 1917-1923. Paris, Inst. d'Etudes slaves. 476 p.

Argenbright, R. (2008). Lethal Mobilities. Bodies and Lice on Soviet Railroads, 1918 1922. In J. of Transport History. Vol. 29. No. 2, pp. 259-276. DOI 10.7227/TJTH.29.2.7.

Belyaeva, M. V. (2002). Rossiiskoe Obshchestvo Krasnogo Kresta v istorii Rossii 1867-1921 gg. [The Russian Red Cross Society in the History of Russia 1867-1921]. Dis. ... kand. ist. nauk. Stavropol', S. n. 211 p.

Budnitskii, O. (2007). Rossiiskie evrei mezhdu krasnymi i belymi (1917-1920) [Russian Jews between Reds and Whites (1917-1920)]. Moscow, ROSSPEN. 547 p.

Bugnion, F. (2000). Le Comité international de la Croix-Rouge et la protection des victimes de la guerre. Genève, CICR. $1444 \mathrm{p}$.

Chistyakov, O. V. (2009). Organizatsionnoe ustroistvo i deyatel'nost' Rossiiskogo obshchestva Krasnogo Kresta v gody Pervoi mirovoi voiny (1914-1918 gg.) [Organisational Structure and Activities of the Russian Red Cross Society during the First World War (1914-1918)]. Dis. ... kand. ist. nauk. Moscow, S. n. 154 p.

CICR (1921). Rapport général du CICR sur son activité de 1912 à 1920. Genève, CICR. 259 p.

Davis, G. H. (1993). National Red Cross Societies and Prisoners of War in Russia, 1914-18. In J. of Contemporary History. Vol. 28. No. 1. pp. 31-52.

Données sur la terreur en Russie présentées par le Comité central de l'ancienne organisation de la Croix Rouge Russe au Comité international de la Croix Rouge à Genève. (1922). Paris, Ed. de la Société russe de la Croix-Rouge. 29 p.

Ensen, B. (1998). Gumanitarnaya pomoshch' i politika: missiya datskogo Krasnogo Kresta v Sovetskoi Rossii. 1918-1919 [Humanitarian Aid and Politics: The Mission of the Danish Red Cross in Soviet Russia. 1918-1919]. In Mal'kov, V. L. (Ed.). Pervaya mirovaya voina. Prolog XX veka. Moscow, Nauka, pp. 515-536.

Fayet, J.-F. (2014). VOKS : le laboratoire helvétique. Histoire de la diplomatie culturelle soviétique durant l'entre-deux-guerres. Genève, Georg. 598 p.

Fayet, J.-F. (2015). Le CICR et la Russie : un peu plus que de l'humanitaire. In Connexes, les espaces postcommunistes en question(s). Bruxelles, Univ. de Geneve, pp. 55-74.

Ferrière, F. (1922). Situation épidémique de la Russie. In Rev. intern. de la Croix Rouge. No. 53, pp. 273-283.

Foust, C. M. (1994). Sanitary Trains and Epidemic Control: The American Red Cross in Siberia during the Russian Civil War. In Carrillo, J., de Ros, G. (Eds.). Actas del XXXIII Congreso Internacional de Historia de la Medicina. Seville, Sociedad Española de Historia de la Medicina, pp. 1005-1010.

GARF [State Archive of the Russian Federation]. Stock 3341. List 1. Dos. 54, 200; List 2. Dos. 52; List 6. Dos. 323; Stock 3342. List 1. Dos. 112; Stock 4094. List 1. Dos. 16, 23, 24, 28, 158, 269; Stock 9501. List 1. Dos. 1, 140, 154; List 5. Dos. 52; List 6. Dos. 6, 7, 8, 11, 17, 36, 39; Stock 9572. List 1. Dos. 20, 27.

Hutchinson, J. F. (1990). Politics and Public Health in Revolutionary Russia. Baltimore, Johns Hopkins Univ. Press. 253 p.

Hutchinson, J. F. (1996). Champions of Charity. War and the Rise of the Red Cross. Colorado, Westview Press. 448 p.

Ippolitov, S. S. (2000). Rossiiskaya blagotvoritel'naya deyatel'nost' na territorii deistvii belykh armii $i v$ emigratsii (1918-1924 gg.) [Russian Charitable Activity on the Territory of Operations of the White Armies and in Emigration (1918-1924)]. Dis. ... kand. ist. nauk. Moscow, S. n. 195 p. 
Irwin, J. F. (2012). The Great White Train: Typhus, Sanitation, and U. S. International Development during the Russian Civil War. In Endeavour. No. 36. Vol. 3, pp. 89-96. DOI 10.1016/j.endeavour.2012.03.001.

Kaldor, M. (2012). New and Old Wars. Organized Violence in a Global Era. Cambridge, Polity Press. 268 p.

Lodyzhenskii, Yu. I. (2007). Ot Krasnogo Kresta k bor'be s kommunisticheskim Internatsionalom [From the Red Cross to the Struggle against the Communist International]. Moscow, Airis Press. 576 p.

Montandon, G. (1923). Deux ans chez Koltchak et chez les Bolchéviques pour la CroixRouge de Genève, 1919-1921. Paris, Alcan. 318 p.

Moreillon, J. (1973). Le CICR et la protection des détenus politiques. Lausanne, L'Age d'Homme. 303 p.

Mukhutdinov, A. A. (1998). Politicheskii Krasnyi Krest. Istoriya sozdaniya $i$ deyatel'nosti; opyt izucheniya massovykh istochnikov [Political Red Cross: History of Creation and Activity; Experience in Studying Mass Sources]. Dis. ... kand. ist. nauk. Moscow, S. n. 157 p.

Patterson, K. D. (1993). Typhus and its Control in Russia, 1870-1940. In Medical History. No. 37, pp. 361-381.

Piana, F. (2016). The Dangers of 'Going Native': George Montandon in Siberia and the International Committee of the Red Cross, 1919-1920. In Contemporary Europ. History. Vol. 25. No. 2, pp. 253-274. DOI 10.1017/S0960777316000060.

Polk, J. A. (2004). The Canadian Red Cross and Relief in Siberia, 1918-1921. MA Thesis, Ottawa, S. n. 243 p.

Polk, J. A. (2012). Constructive Efforts: The American Red Cross and YMCA in Revolutionary and Civil War Russia, 1917-24. PhD Thesis. Toronto, S. n. 507 p.

Quelques documents concernant l'activité de l'ancienne organisation de la CroixRouge russe. (1923). Genève, Ed. de la Société russe de la Croix-Rouge. 40 p.

Toman, J. (1997). La Russie et la Croix-Rouge (1917-1945). La Croix-Rouge dans un Etat révolutionnaire et l'action du CICR en Russie après la Révolution d'octobre 1917. Genève, Inst. Henry-Dunant. $89 \mathrm{p}$.

Weissman, N. B. (1990). Origins of Soviet Health Administration: Narkomzdrav, 1918-1928. In Solomon, S., Hutchinson, J. F. (Eds.). Health and Society in Revolutionary Russia. Bloomington, Indiana Univ. Press, pp. 97-101.

The article was submitted on 11.06.2020 